\title{
Visuomenės dalyvavimo samprata baziniuose pirmojo Lietuvos Nepriklausomybès dešimtmečio sveikatos politikos dokumentuose (1991 - 2002)
}

\author{
Giedrė Baltrušaitytė \\ Vytauto Didžiojo universitetas \\ S. Daukanto g. 28, LT 44246 Kaunas \\ crossref $^{\text {http://dx.doi.org/10.5755/j01.ppaa.18.3.24724 }}$
}

\begin{abstract}
Anotacija. Straipsnyje, remiantis mokslinès literatūros apžvalga bei dokumentu analize nagrinejama, kokia visuomenès dalyvavimo su sveikata susijusiu sprendimu priemime samprata buvo formuluojama pagrindiniuose sveikatos politikos dokumentuose pirmaji dešimtmeti po Lietuvos Nepriklausomybès atkūrimo. Straipsnyje analizuojama 16 sveikatos politikos dokumentu: Nacionaline sveikatos koncepcija (1991), Lietuvos sveikatos programa (1998) ir 1994 - 2002 m. priimti sveikatos sistema reglamentave istatymai, kuriuose kalbama apie visuomenès dalyvavima. Daromos išvados, jog nors visuomenes dalyvavimo svarba pagrindiniuose sveikatos politikos dokumentuose buvo pabrèžiama, tačiau galimybès, kaip visuomene konkrečiai galetu isitraukti i su sveikatos priežiūra susijusiu sprendimu prièmima ir ypač i sveikatos politikos procesus, daugumoje dokumentu nebuvo aiškiai apibrèžtos. Daugelyje nacionalinès svarbos sveikatos politikos dokumentu visuomene matoma kaip poveikio objektas, dominuoja dalyvavimo kaip pacientu isitraukimo priimant savo sveikatai svarbius sprendimus samprata.
\end{abstract}

Raktažodžiai: visuomenès dalyvavimas, sveikatos politika, sveikatos sistema, sveikatos politikos dokumentai

Keywords: public participation, health policy, health system, health policy documents

Ivadas

Aktyvus visuomenès dalyvavimas su sveikata susijusių sprendimų prièmime pastaraisiais dešimtmečiais tapo būtinybe daugelyje demokratinių šalių. Šiuolaikinèje sveikatos politikoje daug dèmesio skiriama tokiems vertybiniams principams kaip žmogaus ir paciento teisès, socialinis teisingumas, solidarumas, o taip pat bendrai atsakomybei už sveikatą, kuri suprantama, kaip aktyvus asmenų, grupių, bendruomenių, institucijų, organizacijų ir sektorių dalyvavimas gerinant sveikatą (Jankauskienė, 2011; p.8). Dalyvavimas kaip esminè geros sveikatos priežiūros dalis apibrèžtas dar 1978 m. Alma Atos deklaracijoje, kurioje teigiama, kad, žmonès turi teisę ir pareigą individualiai ir kolektyviai dalyvauti planuojant ir igyvendinant savo sveikatos priežiūrą" (PSO, 1978).

Visuomenès dalyvavimo samprata nėra vienareikšmė. Bendraja prasme dalyvavimas suprantamas kaip savanoriškas ịsitraukimas i asmeniui, bendruomenei ar visuomenei reikšmingas veiklas bei rūpimų klausimų sprendimą, nors nebūtinai yra susijęs su politiniu kontekstu ar tiesioginiu dalyvavimu valdžioje (Tijūnaitienè ir Damkuvienè, 2010). Visuomenès dalyvavimas gali reikštis ivairiais lygmenimis bei formomis, pradedant asmens motyvacija ar gebėjimu dalyvauti priimant individualius sprendimus iki bendruomenių susitelkimo, viešojo intereso gynimo, galimybès daryti įtaką ar kontroliuoti žmonių gyvenimams svarbių sprendimų priëmimą instituciniame lygmenyje (Petukienè ir kt., 2007; Tijūnaitienè ir Damkuvienè, 2010). Kalbant apie visuomenès dalyvavimą sveikatos sektoriuje, galima būtų išskirti du šio dalyvavimo lygmenis: visuomenès įsitraukimą $\mathfrak{i}$ sveikatos politikos procesus (Thurston ir kt., 2005; Carman ir kt., 2013; Cyril ir kt. 2015) ir asmens ar paciento dalyvavimą priimant konkrečius su gydymu ar sveikatinimusi susijusius sprendimus 
(Eldh ir kt., 2004; Sahlsten ir kt., 2008). Jei socialinis ar politinis visuomenès dalyvavimas aktualizuojamas kaip demokratijos ịgyvendinimo ir visuomeninės gerovės prielaida, tai visuomenès įsitraukimas ị su sveikata susijusių sprendimų prièmimą laikomas dar ir būtina geros asmens ir visuomenès sveikatos sąlyga.

Lietuvoje apie būtinybę ịtraukti visuomenę ị su sveikata susijusių sprendimų prièmimą prabilta po Nepriklausomybès atkūrimo 1990-aisiais pradejjus nacionalinès sveikatos sistemos pertvarką. Sovietmečiu gydytojas buvo tas asmuo, kuriam tekdavo atsakomybè spręsti dèl tinkamiausio pacientui gydymo, o paciento vaidmuo čia buvo minimalus (Bankauskaitè ir Saarelma, 2003). Nors Lietuvos TSR Sveikatos apsaugos įstatymo 6 straipsnyje buvo įtvirtinta nuostata, kad "sveikatos apsaugos organų ir ịstaigų darbe toliau gerinant gyventojų sveikatos apsaugą plačiai dalyvauja visuomenè” (Vyriausybès žinios, 1971, Nr. 35-286), tačiau ši nuostata buvo daugiau deklaratyvaus pobūdžio, nes tiek pati politinè santvarka, itin centralizuotas sveikatos sistemos valdymas, tiek ir vyraujanti siaura medicininè sveikatos samprata nesudare prielaidų aktyvesniam gyventojų įsitraukimui ị sveikatos klausimų sprendimą (Leonavičius ir kt., 2007). Todèl, po Nepriklausomybės atkūrimo 1990-aisiais, nacionalinès sveikatos politikos strategams teko uždavinys ne tik spręsti perimtas sovietinio sveikatos apsaugos modelio problemas, bet ir diegti pažangios sveikatos politikos principus visuomeneje, kuri buvo nepasirengusi aktyviam įsitraukimui. Kita vertus, čia taip pat galima kelti klausimą, kiek patys to laikotarpio Lietuvos sveikatos sistemos pertvarkos kūrèjai galèjo suvokti visuomenès dalyvavimo sveikatos politikos ir sveikatos priežiūros sprendimuose svarbą, nes iki tol šios sritys buvo tiek politiškai, tiek instituciškai stipriai kontroliuojamos (ten pat.).

Atsižvelgiant $\mathfrak{i}$ šị specifini posovietinès visuomenès kontekstą, šiame straipsnyje siekiama atskleisti, kokia visuomenès dalyvavimo samprata, t.y., šio dalyvavimo formos ir būdai, buvo įtvirtinta baziniuose pirmojo Lietuvos Nepriklausomybès dešimtmečio (1991 - 2002) sveikatos politikos dokumentuose. Tikslui pasiekti formuluojami šie uždaviniai: 1) apibūdinti mokslinèje literatūroje pateikiamą visuomenès dalyvavimo su sveikata susijusių sprendimų prièmime sampratą; 2) identifikuoti baziniuose nacionalinès reikšmès sveikatos politikos dokumentuose ịtvirtintas visuomenès dalyvavimo formas; 3) ịvertinti nacionaliniuose sveikatos politikos dokumentuose apibrèžtą visuomenès dalyvavimo sampratą. Straipsnyje bus naudojamasi mokslinès literatūros analize ir kokybine turinio analize, kuri bus taikoma sveikatos politikos dokumentams nagrinèti ir leis vertinti, koks vaidmuo posovietineje sveikatos sistemoje buvo numatytas visuomenei.

Gali kilti klausimas, kodèl šiandien, praejjus beveik trims dešimtmečiams, turètų būti aktualu nagrinèti baziniuose nacionalinès reikšmès sveikatos politikos dokumentuose įtvirtintą visuomenès dalyvavimo sampratą? Tokia analizè yra aktuali visų pirma dèl to, kad pirmąjį nacionalinès sveikatos politikos formavimo dešimtmetị buvo pakloti šiuolaikinès Lietuvos sveikatos sistemos konceptualūs ir teisiniai fundamentai. Todèl tuo laikotarpiu priimtų nacionalinio lygmens sveikatos politikos dokumentų analizè gali padèti geriau suprasti nacionalinès sveikatos sistemos raidos specifiką bei jai kilusius iššūkius ${ }^{1}$. Be abejo, Lietuvos sveikatos politikos strategai formuluodami konceptualinius bei teisinius sveikatos sistemos pagrindus vadovavosi PSO rekomendacijomis ir pažangia demokratinių valstybių praktika, tad dokumentai neišvengiamai atspindès svarbiausiuose tarptautiniuose sveikatos politikos dokumentuose deklaruojamas vertybes bei jų įtvirtinimo principus. Tačiau, kita vertus, kadangi šie dokumentai buvo kuriami specifinėmis istorinėmis, socialinėmis, politinèmis ir ekonominèmis aplinkybėmis, juose neišvengiamai atsispindès ir nacionalinès sveikatos sistemos strategų nuostatos.

Sveikatos politikos ir sistemos formavimo po 1990-ujų eigą bei iššūkius Lietuvos mokslininkai yra nagrinèję gana plačiai. Šie darbai leidžia geriau suprasti nacionalinès sveikatos sistemos pertvarkos kontekstą. Jankauskienè $(2007 ; 2009 ; 2011)$ savo darbuose analizavo Lietuvos sveikatos politikos ir valdymo raidą bei kaitą, vertybinius principus, sveikatos sistemos pertvarkų

\footnotetext{
1 Pavyzdžiui, apžvelgdama sveikatos politikos ir valdymo vystymą pirmuoju sveikatos reformų dešimtmečiu, Jankauskienė (2009) yra atkreipusi dėmesị ị negerèjančią visuomenès sveikatą - ženkliai nuo Europos Sạjungos valstybių atsiliekančią vidutinę gyvenimo trukmę, augantị mirtingumą nuo išvengiamų mirčių.
} 
problemas ir iššūkius; Grabauskas (2003) apžvelgė Lietuvos sveikatos politikos formavimo laikotarpį. Sveikatos priežiūros sistemos pertvarka įvairiais aspektais nagrinèta autorių kolektyvo parengtame leidinyje "Pirmasis reformų dešimtmetis: sveikatos priežiūros sektorius socialiniųekonominių pokyčių kontekste" (2000). Sveikatos priežiūros specifiškumus posovietinejje Lietuvoje yra nagrinėję Leonavičius (2003), Leonavičius ir kt. (2007), Bartuškaitė ir Butkevičienė (2013), Pūras ir kt. (2013), kurie sveikatos sistemos pertvarkos sunkumus siejo ne tik su sudėtingu socialinių, politinių, ekonominių permainų kontekstu, bet ǰžvelgè ir tam tikrų sovietinei sveikatos sistemai būdingų bruožų tąsą po Nepriklausomybès atkūrimo, ypač polinkị sutelkti sveikatos priežiūros sprendimus specialistų rankose.

Lietuvos visuomenès dalyvavimo priimant su sveikata susijusius sprendimus moksliniuose tyrimuose dažniausiai nagrinėjamas pacientu pasitenkinimas ar dalyvavimo galimybès sveikatos priežiūroje (Jankauskienè ir kt., 2008; Jankauskienė, 2012; Peičius ir Kučinskaitė, 2014; Janušonis, 2016). Tuo tarpu visuomenès dalyvavimo sveikatos politikoje tyrimų nėra daug. Paminèti galima Petronytès ir Jasaitytės (2017) tyrimą apie pacientų interesus atstovaujančių nevyriausybinių organizacijų dalyvavimą valstybės sveikatos politikoje. Autorès daro išvadą, kad NVO dalyvavimą valstybės sveikatos politikoje riboja hierarchiniai ryšiai, lygiateisio bendradarbiavimo ir dialogo su valdžios institucijomis stoka. Pastarasis tyrimas aktualizuoja ir šiame straipsnyje nagrinėjamą visuomenès dalyvavimo apibrezžties klojant konceptualius ir teisinius pamatus šiandienos sveikatos sistemai klausimą.

\section{Visuomenès dalyvavimo sveikatai svarbiu sprendimu prièmime formos}

Mokslinèje literatūroje nagrinėjama visuomenès dalyvavimo su sveikata susijusių sprendimų prièmime samprata nėra vienareikšmè. Sąlyginai dalyvavimą su sveikata susijusių sprendimų prièmime būtų galima skirstyti ị visuomenès dalyvavimą įvairiuose sveikatos politikos procesuose ir $\mathfrak{i}$ asmens ar paciento dalyvavimą priimant konkrečius su gydymu ar sveikatinimusi susijusius sprendimus.

Visuomenès dalyvavimas sveikatos politikoje yra procesas, kuomet pacientai ir visuomeniniu organizacijų atstovai ịtraukiami ị sprendimų prièmimą kaip suinteresuotieji subjektai, patarejjai ar disponuojantys pačia sprendimo teise (Thurston ir kt., 2005). Toks visuomenès dalyvavimas gali reikštis pacientų organizacijų ar bendruomenių interesų atstovavimu ịvairiuose komitetuose, tarybose, darbo grupèse, kuriose sprendžiami su sveikata ir sveikatos priežiūros valdymu, planavimu susiję klausimai (Carman ir kt., 2013). Taip pat, gali būti kuriami ịvairūs finansavimo mechanizmai, skatinantys bendruomenes kurti ir igyvendinti joms aktualias sveikatos programas (Cyril ir kt., 2015). Visuomenè gali būti ịtraukiama ir ị sveikatos priežiūros paslaugų planavimą, organizavimą bei kokybės vertinimą (pvz., atliekant sveikatos priežiūros vertinimo, poreikių apklausas) (Souliotis, 2016). Grižtamasis ryšys gaunamas gyventojų apklausų metu leidžia geriau atliepti visuomenès sveikatos poreikius, vertinti paslaugų kokybę ir prieinamumą, pagrịsti ar apibrèžti sveikatos politikos prioritetus, gerinti sveikatos sistemos valdymą (Tritter, 2009).

Kadangi sveikatos politika ir sveikatos priežiūros sprendimai daro ịtaką žmonių gyvenimams, asmens dalyvavimas sprendžiant sveikatos klausimus yra apibrėžiamas kaip pilietinè teisè (Vahdat ir kt., 2014; Tenbensel, 2010). Šios teisès realizavimas sudaro prielaidas igyvendinti teisingumo ir atskaitomybės principais grindžiamą, i paciento ir visuomenès sveikatos poreikius orientuotą sveikatos priežiūrą, kuri geba tinkamiau, efektyviau, kokybiškiau, galiausiai ir ekonomiškiau spręsti sveikatos priežiūros problemas (Souliotis ir kt., 2018).

Asmens ar paciento dalyvavimas sveikatos priežiūroje apibrèžiamas kaip bendradarbiavimas su sveikatos priežiūros specialistais medicininių konsultacijų ar hospitalizacijos metu, siekiant priimti pacientui tinkamiausius, informuotu sutikimu grindžiamus, gydymo ir sveikatinimosi sprendimus (Sahlsten ir kt., 2008). Asmens dalyvavimas sveikatos priežiūroje taip pat siejamas su atsakomybès už sveikimą bei sveikatinimąsi prisièmimu (Eldh ir kt., 2004). Paciento dalyvavimas igalinamas tiek skatinant sveikatos priežiūros specialistus įtraukti pacientus ị jų sveikatos priežiūros sprendimų prièmimą, tiek teisiškai įtvirtinant pacientų teises (pvz., teisę atsisakyti gydymo ir t.t.). Mokslinèje 
literatūroje pabrèžiama tokio pacientų dalyvavimo svarba: tyrimai rodo, kad aktyvus pacientų ir sveikatos priežiūros specialistų bendradarbiavimas yra susijęs su geresniais gydymo rezultatais (Arnetz ir kt., 2008), teigiamais pokyčiais žmonių sveikatos elgsenoje ir sąmoningumu bei atsakomybe sveikatos atžvilgiu (Williamson, 2014). Taip pat, paciento ịtraukimas ì su gydymu susijusių sprendimų prièmimą yra reikšmingas pasitenkinimo sveikatos priežiūros paslaugomis veiksnys (Thornton ir kt., 2017). Iš esmès sutariama, kad visuomenès ar asmens sveikatinimas bus trumpalaikis ir neefektyvus, jei sveikatinimo sprendimai bus ,nuleidžiami iš viršaus“ (Williamson, 2014).

Kita vertus, nors visuomenès dalyvavimo su sveikata susijusių klausimų sprendime būtinybè formaliai yra deklaruojama daugelyje šiuolaikinių sveikatos politikos dokumentų, tačiau realiai tokio dalyvavimo galimybès gali būti ribotos. Callaghan ir Wistow (2006), pavyzdžiui, kelia klausimą, kiek pacientų visuomeninès organizacijos geba apginti savo interesus, kiek jų atstovai yra lygiaverčiai su gydytojais ar politikos formuotojais bei igyvendintojais priimant pacientams aktualius sprendimus ir ižvelgia tam tikrus interesų konfliktus tarp skirtingų sveikatos sistemos lauko veikejjų. Tradiciškai bet kokie sprendimai šiame lauke buvo ir daugeliu atveju išlieka grindžiami ekspertinèmis (mokslinėmis) specialistų žiniomis, o kitos žinojimo formos vertinamos kaip nepakankamai pagrịstos ar adekvačios (Bryant, 2002). Todèl sprendimų prièmimo procese ekspertinis žinojimas dominuoja kitų žinojimo formų atžvilgiu, be to iš šio žinojimo kylanti specialistų galia spręsti dažnai yra institucionalizuota, kai tuo tarpu visuomenès - ne.

Callaghan ir Wistow (2006) atkreipia dėmesi ir i terminologiją, kuria apibrèžiamas visuomenès vaidmuo sveikatos politikoje ir priežiūroje. Tam tikri dokumentuose vartojami terminai implikuoja skirtingas dalyvavimo formas. Šiandien gana plačiai vartojamas terminas sveikatos priežiūros paslaugų vartotojas nurodo iš esmès asmenini interesą ir poreikius tenkinančio asmens santyki su sveikatos priežiūra. Vartotojas turi teisę i jo lūkesčius atliepiančias paslaugas, jis gali reikalauti kokybės iš sveikatos priežiüros paslaugu teikëjo, tačiau iš esmès vartotojo dalyvavimas sveikatos priežiūroje ar sveikatos politikos procesuose yra trumpalaikis, grindžiamas labiau asmeniniu nei viešuoju interesu. Vartotojas turi teisę dalyvauti, bet tuo pačiu ir teisę nedalyvauti (Callaghan ir Wistow, 2006; p. 585; Jung, 2010).

Terminas pilietis ženklina teisinès, politinès ir socialinès narystės bendruomenejje teisètumą. Piliečių dalyvavime prioretizuojami kolektyviniai interesai, todėl piliečių dalyvavimas peržengia asmeninį poreikị ir suponuoja prielaidas aktyvesniam įsitraukimui i sveikatai svarbių sprendimų prièmimo procesus. Piliečiai gali pareikalauti tam tikros atskaitomybès tiek iš politikų, tiek iš sveikatos sistemos valdymo institucijų, tad iš dalies jų balsas priimant sveikatai svarbius sprendimus yra svaresnis nei vartotojų (Jung, 2010).

Skirtumas tarp pacientu ir visuomenès nèra toks aiškus. Šie du statusai iš dalies gali sutapti, nors, jei pacientai dalyvaudami priimant su sveikata susijusius sprendimus gali remtis sveikatos priežiūros patirtimi, tai visuomenès indėlis šiuo atveju sunkiau identifikuojamas (Callaghan ir Wistow, 2006; Tritter, 2009). Kita vertus, pats terminas pacientas implikuoja tam tikras šio vaidmens ribas: paciento vaidmuo apima tam tikras teises ir pareigas sveikatos priežiūros institucijose, tačiau sprendžiant visuomenès sveikatai aktualius klausimus, kurie išeina už sveikatos priežiūros ribų, šis vaidmuo gali riboti dalyvavimą.

\section{dokumentuose}

Visuomenès dalyvavimo apibrëžtis 1991 - 2002 m. nacionaliniuose sveikatos politikos

Metodologija. Šioje straipsnio dalyje nagrinejjama visuomenės dalyvavimo apibrèžtis taip vadinamuose pamatiniuose, pirmajị dešimtmetị po Lietuvos Nepriklausomybès atkūrimo priimtuose sveikatos politikos dokumentuose, kurie formavo teisinius Lietuvos sveikatos sistemos pagrindus. Analizuojami tik tie dokumentai, kuriuose yra kalbama apie visuomenès dalyvavimą. I analizę ịtraukti šie dokumentai: Lietuvos nacionalinè sveikatos koncepcija (1991), Lietuvos sveikatos programa (1998), Sveikatos sistemos įstatymas (1994), Psichikos sveikatos priežiūros įstatymas (1995), Alkoholio kontrolès ịstatymas (1995), Tabako kontrolès (1996), Sveikatos draudimo 
įstatymas (1996), Sveikatos priežiūros ịstaigų ịstatymas (1996), Pacientų teisių ir žalos sveikatai atlyginimo ịstatymas (1996), Stomatologinès priežiūros ịstatymas (1996), Gydytojo medicinos praktikos istatymas (1996), Kraujo donorystès įstatymas (1996), Žmonių užkrečiamųjų ligų profilaktikos ir kontrolès įstatymas (1996), Narkologinès priežiūros įstatymas (1997), Maisto įstatymas (2000), Visuomenès sveikatos priežiūros ịstatymas (2002). Dokumentai analizuojami taikant kokybinès turinio analizès principus, kuomet gilinamasi i dokumento turinị ieškant tyrimui svarbių analitinių vienetų reikšmių.

Rezultatai. Atkūrus Lietuvos Nepriklausomybę, $1991 \mathrm{~m}$. Lietuva ịstojo ị Pasaulinę sveikatos organizaciją, kurios patirtimi buvo remiamasi plètojant sveikatos politiką ir kuriant nacionalinę sveikatos priežiūros sistemą. Tais pačiais metais buvo parengta ir LR Aukščiausiosios Tarybos patvirtinta Nacionalinė sveikatos koncepcija (LR Aukščiausiosios Tarybos $1991 \mathrm{~m}$. spalio 30 d. nutarimas Nr. I-1939), kurioje buvo suformuluotos sveikatos priežiūros sistemos perspektyvinès kryptys ir reformos principai.

Nacionalinè sveikatos koncepcija buvo grindžiama biopsichosocialine sveikatos samprata, jau keletą dešimtmečių vyravusia demokratinių šalių sveikatos politikoje. Remiantis šia samprata sveikata apibrèžiama kaip visapusiška individo bei visuomenès fizinè, dvasinè ir socialinè gerovė, o ne tik ligų ar fizinių negalių nebuvimas (Žin., 1991-11-30, Nr. 33-893). Koncepcijoje sveikata matoma ne tik kaip valstybės ar sveikatos priežiūros sistemos, bet ir kiekvieno jos nario reikalas. Valstybe turi sudaryti būtinas sąlygas visuomenei bei kiekvienam jos nariui gyventi sveikai, visuomenè turi būti informuota sveikatos klausimais tam, kad galètų aktyviai dalyvauti valdant sveikatos sistemą, o kiekvienas pilietis matomas, kaip aktyviai siekiantis sveikatos (II skyrius 3 punktas).

Teisè į informaciją yra matoma, kaip aktyvaus visuomenès ir kiekvieno jos nario dalyvavimo sveikatos išsaugojime pagrindas. Valstybè turinti užtikrinti piliečių teisę i informaciją apie aplinkos būklę ir gaminamos produkcijos kokybę (IV skyriaus 4 punktas). Dokumentu ịtvirtinama ir kita svarbi teisè, kuri galètų būti traktuojama kaip aktyvaus paciento vaidmens dalis, tai laisvė kreiptis į bet kurią medicinos tarnybą (VI Koncepcijos straipsnis, 2 punktas). Koncepcijoje buvo numatytas ir dar vienas punktas, kuris žymėjo kintančią sveikatos priežiūros sampratą ir paciento vaidmeni joje: pacientas turi teisę gauti kompensacijas medicininès klaidos atveju (IX skyrius 6 punktas).

Lietuvos nacionaline sveikatos koncepcija, kaip kad nusako pats dokumento pavadinimas, buvo siekiama suformuoti nacionalinès sveikatos sistemos koncepciją ir nubrèžti gaires tolesnei sistemos plètotei, todèl dokumente tik ittvirtinama visuomenès, piliečių ir pacientų dalyvavimo svarba, tačiau koks konkrečiai turètų būti visuomenès vaidmuo nèra išplètojama.

Koncepcijoje numatyti sveikatos tausojimo bei stiprinimo, ligų profilaktikos prioritetai tapo pagrindu kuriant Lietuvos sveikatos programą (1998), kurioje buvo ịsipareigota siekti tokių tikslų, kaip gyventojų mirtingumo mažinimas ir vidutinès gyvenimo trukmės ilginimas; sveikatos santykių teisumas; gyvenimo kokybès pagerinimas (Žin., 1998-07-17, Nr. 64-1842). Galima teigti, kad šių tikslų igyvendinimas iš esmès yra neatsiejamas nuo aktyvaus visuomenès ir kiekvieno jos nario įsitraukimo.

Gyvenimo kokybės gerinimas (III skyriaus 1.3. punktas) Programoje tiesiogiai siejamas su aktyviu gyventojų dalyvavimu visuomenès gyvenime ir sveikatos politikos formavime bei sveikos gyvensenos, kaip socialinès normos ịtvirtinimu (o tai reikštų ir sąmoningesnị visuomenès požiūrị i savo sveikatą), tačiau gyvenimo kokybès gerinimo tikslas ir jo ịgyvendinimas dokumente liko mažai išplètoti.

Kokị vaidmenị visuomenei buvo numatę ar kaip ji suprato Programos kūrèjai iš dalies galima vertinti pagal specialiujų tikslų igyvendinimo formulavimą, taip pat pagal integruoto poveikio būdų (IV skyrius) igyvendinimo ir prioritetinių sveikatinimo veiklos krypčių pristatymą (V skyrius).

Specialieji Programos tikslai (III skyriaus 2 dalis) apėmė ịvairias problemines ar spręstinas visuomenès sveikatos ir sveikatos priežiūros sritis: lètines $(2.1,2.2,2.7)$, užkrečiamasias (2.5.1, 2.5.3), lytiniu keliu plintančias (2.5.2) ligas, imunoprofilaktiką (2.5.4), psichikos ligas ir savižudybes (2.4), nelaimingus atsitikimus ir traumatizmą (2.3) ir burnos sveikatą (2.6). Iš esmès tik trijų iš 
dešimties specialiujų tikslų igyvendinime visuomenė buvo matoma kaip aktyvi dalyvė (pvz., dokumente numatyta i gyventojų sveikatos stiprinimą ir išsaugojimą įtraukti visuomenės organizacijas, skatinti "Sveikų miestų“ ir pan. judejjimus, siekti glaudaus bendradarbiavimo su nevyriausybinèmis organizacijomis sprendžiant diabetologijos problemas). Siekiant daryti poveiki specifinèms visuomenès sveikatos problemoms pagrindine priemone Programoje laikomas visuomenès informavimas, švietimas, sveikatą palaikančių igūdžių ugdymas ir pan. Galima daryti prielaidą, jog kadangi specialieji tikslai žymėjo konkrečias sveikatos ar medicinines problemas, ju sprendimo būdai tuo metu buvo matomi daugiau kaip sveikatos priežiūros specialistų reikalas.

Analizuojant integruoto poveikio būdus (IV skyrius), taipogi matoma, kad visuomenè traktuojama daugiau kaip poveikio objektas (numatoma ją informuoti gyvensenos klausimais, pvz., mokyti mitybos principų ir t.t.), kita vertus, kalbama ir apie visuomenininių organizacijų ịsitraukimą, pvz., formuojant ir igyvendinant tabako kontrolès politiką (1.1.1. punktas), vykdant prieš narkomaniją nukreiptus projektus (1.1.3 punktas), remiant visuomenès veiksmus, nukreiptus alkoholio sukeltos žalos profilaktikai ir pagalbai asmenims kenčiantiems nuo jo (1.1.2 punktas).

Visuomenès dalyvavimas minimas artimuosiuose (iki 2005 m.) šios Programos dalies uždaviniuose. Pirmame uždavinyje kalbama apie siekị tobulinti sveikatos priežiūros valdymo struktūrą ir iš to sekančią galimybę visuomenei dalyvauti priimant sprendimus dèl sveikatos priežiūros (IV skyrius, 3.2 skirsnis). Šio dalyvavimo prielaida laikomos bendruomenès sveikatos tarybos savivaldybėse, taip pat Nacionalinè sveikatos taryba.

Programos V skyriuje, apibrėžiant prioritetines sveikatinimo veiklos kryptis, dar kartą užsimenama apie visuomenès dalyvavimą. Dokumente nurodoma, jog sveikatos programų rengimu siekiama ,itraukti visuomenę i s sveikatos politikos formavimą“ (Žin., 1998-07-17, Nr. 64-1842). Dokumente taip pat nurodoma, kad „<...> Turi būti atliekamos gyventojų apklausos bei jų pačių sveikatos kokybès vertinimas, žinių apie savo sveikatą igijimas bei dalyvavimas sprendžiant sveikatos priežiūros valdymo problemas“(Žin., 1998-07-17, Nr. 64-1842).

Taigi, Lietuvos sveikatos programoje buvo nemažai kalbama apie visuomenès dalyvavimą, vis tik galima kelti klausimą, kiek jos kūrèjai suvokè šio dalyvavimo reikšmę, nes iš esmès Programoje visuomenè daugiau matoma kaip poveikio objektas ${ }^{2}$.

Straipsnyje apžvelgiamu laikotarpiu, kuriant ir reformuojant Nepriklausomos Lietuvos SPS, buvo priimta eilè įstatymų, kurie buvo svarbūs apibrèžiant visuomenès dalyvavimą.

Sveikatos sistemos istatymas (1994) yra bazinis teisinis dokumentas, reglamentuojantis Lietuvos nacionalinę sveikatos sistemą, jos valdymą, gyventojų, sveikatinimo veiklos subjektų teises ir pareigas. Istatymo I dalies, I skyriaus 6 straipsnyje nurodoma, kad sveikatinimo veikla reguliuojama remiantis tokiais principais, kaip: "asmens sveikatos priežiūros priimtinumas, prieinamumas ir tinkamumas; asmenų laisvė vienytis į visuomenines organizacijas, ginančias asmens ir visuomenès sveikatos interesus, ir valstybès parama šių organizacijų veiklos programoms; visapusiškas, teisingas ir nepavèluotas visuomenès informavimas apie kuo geresnès sveikatos ugdymo sąlygas ir šių sąlygų reklama; visuomeninių organizacijų dalyvavimas sveikatinimo veiklos valdyme tiek tiesiogiai, tiek per demokratiškai išrinktus savo atstovus“ (Žin., 1994-08-17, Nr. 631231).

Sveikatos sistemos įstatymas nagrinèjant visuomenès vaidmenį priimant su sveikata susijusius sprendimus yra aktualus tuo, kad jame buvo konkretizuoti visuomenès dalyvavimo būdai. IV Istatymo dalyje reglamentuojami sveikatinimo veiklos valdymo pagrindai. Šioje įstatymo dalyje numatomos visuomeninių organizacijų, ginančių visuomenès sveikatos interesus veiklos programų rėmimo būdai (IV dalis, I skyrius, 82 straipsnis), taip pat sveikatinimo veiklos subjektų finansavimo šaltiniai (IV dalis, III skyrius, 98 straipsnis). V-oje įstatymo dalyje apibrèžiama Lietuvos nacionalinės sveikatos sistemos (LNSS) valdymo subjektų kompetencija. III-iame šios dalies skyriuje apibrėžiamos LNSS veiklos koordinavimo institucijos ir funkcijos. Išskiriamos dvi pagrindinès institucijos koordinuojančios sveikatos politiką - Nacionalinė sveikatos taryba (NST) ir Savivaldybės

\footnotetext{
${ }^{2}$ Kaip pastebi Murauskienè (2000; p.164), Lietuvos sveikatos programa buvo gana „medicinine““.
} 
bendruomenės sveikatos taryba (SBST). Šios institucijos yra svarbios tuo, kad i jų sudètị ịtraukiami visuomeninių organizacijų, ginančių visuomenès sveikatos interesus, atstovai (1/3 NST ir SBST narių yra visuomenès atstovai).

İstatyme buvo įtvirtintos tam tikros sveikatinimo veiklos būtinosios sąlygos, kurios suteikè daugiau teisių asmenims patiems priimti sveikatos priežiūros sprendimus: asmens sutikimas gauti sveikatos priežiūros paslaugas (II dalis, I skyrius, 15 straipsnis), priverstinès hospitalizacijos, diagnostikos bei gydymo priemonių apribojimai (II dalis, II skyrius, 20 straipsnis). Istatymu buvo apibrezžtos ir kitos gyventojų teisès sveikatos priežiūros institucijose ir sveikatinimo veikloje (VI dalis, I skyrius, 132 straipsnis), tarp kurių ir teisė dalyvauti nustatant sveikatos priežiūros plètojimo prioritetines kryptis, kontroliuojant sveikatos priežiūros prieinamumą ir tinkamumą. Pacientų teisès toliau buvo ịtvirtinamos Psichikos sveikatos priežiūros (1995), Stomatologinès priežiūros (1996), Sveikatos draudimo (1996), Sveikatos priežiūros įstaigų (1996), Pacientų teisių ir žalos sveikatai atlyginimo (1996), Gydytojo medicinos praktikos (1996), Kraujo donorystès (1996), Žmonių užkrečiamujų ligų profilaktikos ir kontrolès (1996), Narkologinès priežiūros (1997) įstatymais.

Aktualus šiame straipsnyje analizuojamam objektui yra ir Sveikatos priežiūros ịstaigu ịstatymas (1996), kuris apibrèžè sveikatos priežiūros ịstaigų tipus, jų valdymo ypatumus, santykius tarp sveikatos priežiūros ịstaigų ir pacientų. II-ame šio ịstatymo skyriuje, 31 straipsnyje apibrezžiami Lietuvos nacionalinès sveikatos sistemos viešuju isstaigu patariamieji valdymo organai. Pagal ši straipsnį, visų lygmenų - pirminio, antrinio, tretinio - LNSS įstaigos privalo turèti stebètojų tarybą, kuri yra patariamasis organas, sudaromas penkeriems metams. İstatymo II skyriaus 33 straipsnis apibrėžè šios tarybos sudètį: ị tarybą įtrauktas vienas savivaldybès, kurios teritorijoje yra ịstaiga, tarybos paskirtas visuomenès atstovas (Žin., 1996-07-12, Nr. 66-1572). ${ }^{3}$

Sveikatos draudimo ịstatymas (1996) apibrěžè tam tikras draudžiamujų teises, tačiau sprendžiant sveikatos draudimo klausimus visuomenès dalyvavimas šiame dokumente nèra numatomas. İstatymo IV skyriuje apibrèžiant Privalomojo sveikatos draudimo tarybos funkcijas ir sudètį, nekalbama apie visuomeninių organizacijų galimybes įsitraukti ị joms aktualių sprendimų prièmimą (žr. Žin., 1996-06-12, Nr. 55-1287), nors pacientų visuomeninèms organizacijoms greičiausiai būtų aktualu dalyvauti svarstant asmens sveikatos priežiūros paslaugų, apmokamų iš privalomojo sveikatos draudimo fondo biudžeto, sąrašo ir kitus klausimus

Visuomenès sveikatos priežiūros įstatymas (2002) apibrèžė visuomenės sveikatos priežiūrą. Šiame įstatyme visuomenės gebejjimas gerinti sveikatą pagrinde matomas, kaip sveikos gyvensenos propagandos ir gyventojų sveikatos ugdymo klausimas, nors İstatymo III skyriaus 1 skirsnio 10 straipsniu ịtvirtinama ir galimybė visuomenei dalyvauti viešai svarstant Lietuvos nacionalinès visuomenès sveikatos priežiūros strategijos ịgyvendinimo rezultatus (Žin., 2002-06-07, Nr. 56-2225).

Alkoholio kontrolès (1995), Tabako kontrolès (1996) ir Narkologinès priežiūros (1997) įstatymuose visuomenè matoma tiek kaip poveikio objektas (būtina informuoti visuomenę apie psichiką veikiančių medžiagų vartojimo poveikį sveikatai, taip pat šio vartojimo socialinę ir ekonominę žalą), tiek kaip sveikatinimo subjektas (išskyrus Narkologinès priežiūros įstatymą). Pavyzdžiui, Alkoholio kontrolès ịstatymo I skyriaus 3 straipsnyje pristatant pagrindinius valstybès alkoholio kontrolès politikos principus, numatoma remti sveikatos ir blaivybès organizacijų veiklos, nukreiptos į alkoholio vartojimo mažinimą gyventojų tarpe, programas (Žin., 1995-05-26, Nr. 441073). Tabako kontrolès ịstatymo III skyriaus 16 straipsnyje ịtvirtinama nuostata, kad tabako kontrolès programas gali rengti ir visuomeninès organizacijos. Jos taip pat gali teikti pasiūlymus LR Vyriausybei, Nacionalinei sveikatos tarybai ir kitoms valstybès tabako kontrolès politiką formuojančioms ir igyvendinančioms institucijoms dèl tabako kontrolès programu rengimo ir igyvendinimo (Žin., 1996, Nr. 11-281).

\footnotetext{
${ }^{3}$ LNSS viešosios įstaigos (išskyrus valstybės aukštųjų mokyklų ar valstybinių mokslo įstaigų ir Sveikatos apsaugos ministerijos įsteigtas įstaigas) stebètojų taryba sudaroma iš 5 narių; Valstybès aukštųjų mokyklų ar valstybinių mokslo įstaigų ir Sveikatos apsaugos ministerijos įsteigtų įstaigų stebètojų taryba sudaroma iš 7 narių (Žin., 1996-07-12, Nr. 66-1572).
} 
Analizuojamu laikotarpiu priimtas Maisto istatymas (2000) reglamentavo vartotojų teises ir jų gynimą. Tai yra pirmas nacionalinès sveikatos politikos dokumentas po Nepriklausomybès atkūrimo, kuriame atsiranda terminas vartotojas ir kuriame kalbama apie šios tikslinès grupès interesus maisto saugos, kokybès bei informavimo apie tai srityse (Žin., 2000-04-19, Nr. 32-893). Istatymo III skirsnio 10 strapsnyje nurodoma, kad vartotojų teises atstovauja visuomeninès vartotojų teisių gynimo organizacijos, turinčios teisę tirti vartotojų nuomonę, kreiptis ị teismą dèl vartotojo teisių ar interesų pažeidimų, gauti informaciją iš gamintojų ir pardavejjų apie maisto saugą ir kokybę, steigti informavimo ir konsultavimo centrus bei bandymų laboratorijas maisto saugai ir kokybei tirti, stebėtojo teisėmis dalyvauti Nacionalinès vartotojų teisių apsaugos tarybos posėdžiuose ir teikti pasiūlymus dẻl priemonių vartotojų teisių gynimui gerinti ar informuoti apie maisto saugą ir kokybę reglamentuojančių teisès aktų pažeidimus ir t.t. (Žin., 2000-04-19, Nr. 32-893). Taigi, įstatymu ịtvirtinamas aktyvus vartotojų teises ir interesus atstovaujančių visuomeninių organizacijų vaidmuo maisto saugos ir kokybès gerinimo srityje.

Lentelèje 1 pateikiamas visuomenès dalyvavimo sampratos analizès sveikatos politikos dokumentuose apibendrinimas.

Lentele 1 . Visuomenès dalyvavimo samprata pagrindiniuose sveikatos politikos dokumentuose.

\begin{tabular}{|c|c|c|c|}
\hline Dokumentas & $\begin{array}{l}\text { Pacientų } \\
\text { teisès }\end{array}$ & $\begin{array}{l}\text { Visuomenès } \\
\text { informavimas }\end{array}$ & $\begin{array}{l}\text { Visuomenès } \\
\text { dalyvavimas } \\
\text { sveikatos } \\
\text { politikoje }\end{array}$ \\
\hline Lietuvos nacionalinè sveikatos koncepcija (1991) & $\checkmark$ & $\checkmark$ & $\checkmark$ \\
\hline Lietuvos sveikatos programa (1998) & & $\checkmark$ & $\sqrt{ }$ \\
\hline Sveikatos sistemos įstatymas (1994) & $\checkmark$ & $\checkmark$ & $\sqrt{ } \sqrt{ }$ \\
\hline Psichikos sveikatos priežiūros įstatymas (1995) & $\checkmark$ & & \\
\hline Alkoholio kontrolès įstatymas (1995) & $\checkmark$ & $\checkmark$ & $\checkmark \checkmark \checkmark$ \\
\hline Tabako kontrolès (1995) & $\checkmark$ & $\checkmark$ & $\checkmark \sqrt{ }$ \\
\hline Sveikatos draudimo įstatymas (1996) & $\checkmark$ & & \\
\hline Sveikatos priežiūros įstaigų ịstatymas (1996) & & & $\sqrt{ } \sqrt{ }$ \\
\hline Pacientų teisių ir žalos sveikatai atlyginimo įstatymas (1996) & $\checkmark$ & & \\
\hline Stomatologinès priežiūros įstatymas (1996) & $\checkmark$ & & \\
\hline Gydytojo medicinos praktikos įstatymas (1996) & $\checkmark$ & & \\
\hline Kraujo donorystès įstatymas (1996) & $\checkmark$ & & \\
\hline $\begin{array}{l}\text { Žmonių užkrečiamųjų ligų profilaktikos ir kontrolès įstatymas } \\
\text { (1996) }\end{array}$ & $\checkmark$ & $\checkmark$ & \\
\hline Narkologinės priežiūros ịstatymas (1997) & $\checkmark$ & $\checkmark$ & \\
\hline Maisto įstatymas (2000) & $\checkmark$ & $\checkmark$ & $\checkmark \sqrt{ } \sqrt{ }$ \\
\hline Visuomenès sveikatos priežiūros ịstatymas (2002) & & $\checkmark$ & $\sqrt{ }$ \\
\hline
\end{tabular}

Šaltinis: sudaryta autorès.

Varnele lentelèje pažymėta, kokia forma (t.y., per pacientų teisių įtvirtinimą, visuomenès informavimą sveikatos klausimais, visuomenès dalyvavimą sveikatos politikoje) matomas visuomenès dalyvavimas atskiruose dokumentuose. Dvejomis varnelėmis pažymèti dokumentai, kuriuose yra numatomi ir visuomenès dalyvavimo sveikatos politikoje būdai, trejomis - kuomet šis dalyvavimas yra institucionalizuotas.

Taigi, kaip matyti lentelèje 1, analizuojamo laikotarpio nacionaliniuose sveikatos politikos dokumentuose visuomenès dalyvavimas daugiausiai apibrěžiamas per pacientų teises. Iš 16 analizuotų dokumentų, septyniuose yra kalbama apie visuomenès dalyvavimo sveikatos politikoje būdus (pvz., viešas sveikatai ar sveikatos priežiūrai aktualių sprendimų svarstymas ir pan.), o 
penkiuose dokumentuose šie dalyvavimo būdai yra institucionalizuojami (pvz., visuomenè dalyvauja sveikatos politikoje per ją koodinuojančias institucijas (NST, SBST), LNSS stebėtojų tarybas, visuomeninių vartotojų teisių gynimo organizacijoms suteikiamas teises, taip pat numatant finansinès paramos šaltinius visuomeninių organizacijų sveikatinimo veikloms).

Taigi, bent formaliai, baziniuose sveikatos politikos dokumentuose buvo deklaruojama visuomenès dalyvavimo svarba. Kita vertus, nors visuomenès dalyvavimo svarba ir buvo pabrěžiama, tačiau būdai, kaip visuomenė galètų konkrečiai ịsitraukti ị su sveikata bei sveikatos priežiūra susijusių sprendimų prièmimą, ir ypač ị sveikatos politikos procesus, daugelyje dokumentų nebuvo aiškiai apibrèžti. Dokumentuose dominuojanti dalyvavimo kaip pacientų teisių realizavimo samprata be abejo ženklino ryškų paciento vaidmens pokyti posovietinèje sveikatos sistemoje, tačiau tokia dalyvavimo samprata yra gana siaura, nes dalyvavimas šiuo atveju dažniausiai neišeina iš už sveikatos priežiūros institucijų ar gydytojo ir paciento santykių ribų. Tuo tarpu visuomenès dalyvavimo sprendžiant kolektyvinius visuomenès sveikatai aktualius klausimus svarba yra grindžiama požiūriu, kad sveikata yra ne tik paciento, sveikatos priežiūros specialistų ar sveikatos priežiūros sistemos reikalas, bet reikalauja aktyvaus grupių, bendruomenių, institucijų, organizacijų ir kitų visuomenès sektorių ịsitraukimo. Čia galima būtų grịžti prie klausimo, kiek to laikotarpio sveikatos politikos strategai suvokè visuomenès dalyvavimo svarbą, o kiek deklaratyviai perèmé tarptautiniuose dokumentuose įtvirtintas nuostatas. Atsakymas i ši klausimą reikalauja tolesnių tyrimų, tačiau galima kelti prielaidą, kad formuojant konceptualius ir teisinius sveikatos sistemos pamatus visuomenės dalyvavimo svarba greičiausiai dar nebuvo pakankamai įsisąmoninta.

\section{Išvados}

1. Mokslinèje literatūroje pateikiama visuomenès dalyvavimo su sveikata susijusių sprendimų prièmime samprata nèra vienareikšmè. Išskiriamios ịvairios visuomenès dalyvavimo formos: nuo asmens atsakomybės už savo sveikatą prisiẻmimo, aktyvaus pacientų ịsitraukimo ị gydymo ir gydymosi procesą iki visuomenès interesų atstovavimo ir dalyvavimo patarèjų ar sprendimo priemėjų teisèmis įvairiose valdžios institucijose, kuriose sprendžiami su sveikata ir sveikatos priežiūra susiję klausimai. Sąlyginai mokslinèje literatūroje nagrinėjamą visuomenès dalyvavimo sampratą galima skirstyti $\mathfrak{i}$ visuomenès dalyvavimą sveikatos politikos procesuose ir $\mathfrak{i}$ asmens ar paciento dalyvavimą priimant konkrečius su gydymu ar sveikatinimusi susijusius sprendimus.

2. Apibendrinant bazinių sveikatos politikos dokumentų, kurie buvo priimti pirmąji Lietuvos Nepriklausomybės atkūrimo dešimtmetị, analizę galima išskirti keletą pagrindinių šiuose dokumentuose apibrèžtų visuomenès dalyvavimo priimant sveikatai svarbius sprendimus formų: 1 . Pacientams suteikiamos ịstatymiškai įtvirtintos teisès spręsti savo asmens sveikatos priežiūros klausimus 2. Visuomené šviečiama sveikatos klausimais ir taip tampa aktyvesnè ir sąmoningesnè sveikatos atžvilgiu; 3. Visuomenė dalyvauja sveikatinimo veiklos valdyme (pvz. per šią veiklą koodinuojančias institucijas ar patariamuosius valdymo organus).

3. Nors baziniuose nacionalinès reikšmès sveikatos politikos dokumentuose pabrèžiama visuomenès dalyvavimo svarba, tačiau būdai, kuriais visuomenė galėtų konkrečiai ịsitraukti i su sveikata bei sveikatos priežiūra susijusių sprendimų prièmimą daugumoje dokumentų nebuvo aiškiai apibrėžtos. Visuomenè daugiau matoma kaip poveikio objektas, dominuoja dalyvavimo kaip pacientų isitraukimo priimant savo sveikatai svarbius sprendimus samprata.

\section{Pastabos}

Straipsnis parengtas remiantis tyrimu, kuris finansuojamas pagal LMT programą Modernybė Lietuvoje. Tyrimo projektas: Lietuvos visuomenès modernizacija amžių sandūroje: tęstinumas ir pertrūkiai. Sutarties Nr. MOD-17038. 


\section{Literatūra}

1. Arnetz, J.E, Winblad, U., Arnetz, B.B., Hoglund, A.T. Physicians' and Nurses' Perceptions of Patient Involvement in Myocardial Infarction Care. European Journal of Cardiovascular Nursing, 2008, Vol.7, No.2, p. 113-120.

2. Bankauskaite, V., Saarelma, O. Why are People Dissatisfied with Medical Care Services in Lithuania? A Qualitative Study Using Responses to Open-ended Questions. International Journal for Quality in Health Care, Vol.15, No. 1, p. 23-9.

3. Bartuškaitè, M., Butkevičienè, E. Lietuvos gyventojų požiūris i sveikatos priežiūros sistemą ir alternatyviąją mediciną. Viešoji politika ir administravimas, 2013, T. 12, Nr. 1, p. 94-107.

4. Bryant, T. Role of Knowledge in Public Health and Health Promotion Policy Change. Health Promotion International, 2002, Vol.17, No.1, p.89-98.

5. Callaghan, G.D., Wistow, G. Publics, Patients, Citizens, Consumers? Power and Decision Making in Primary Health Care. Public Administration, 2006, Vol.84, No.3, p.583-601.

6. Carman, K.L., Dardess, P., Maurer, M., Sofaer, S., Adams, K., Bechtel, C., Sweeney, J. Patient and Family Engagement: A Framework for Understanding the Elements and Developing Interventions and Policies. Health Affairs, 2013, Vol. 32, No.2, p. 223-31.

7. Cyril, S., Smith, B.J., Possamai-Inesedy, A., Renzaho, A.M. N. Exploring the Role of Community Engagement in Improving the Health of Disadvantaged Populations: a Systematic Review. Global Health Action, 2015, No. 8, p. 1-12.

8. Černiauskas, G.; Dobravolskas, A.; Murauskienè, L. Pirmasis reformu dešimtmetis: sveikatos priežiūros sektorius socialiniu-ekonominiu pokyčiu kontekste. Vilnius: Sveikatos ekonomikos centras, 2000.

9. Eldh, A.C, Ehnfors, M., Ekman, I. The Phenomena of Participation and Non-Participation in Health Care--Experiences of Patients Attending a Nurse-Led Clinic for Chronic Heart Failure. European Journal of Cardiovascular Nursing, 2004, Vol.3, No.3, p. 239-246.

10. Epstein, R., Peters, E. Beyond Information: Exploring Patients' Preferences. Journal of the American Medical Association, 2009, Vol.302, No.2, p. 195-197.

11. Grabauskas, V. Nuo klasikinių epidemiologinių tyrinèjimų iki sveikatos politikos formavimo (Kauno-Roterdamo epidemiologinès programos patirtis). Medicina, 2003, T. 39, Nr. 12, p.11841192.

12. Jankauskienè, D. Sveikatos apsaugos valdymo tobulinimo kryptys. Visuomenès sveikata, 2007, Nr. 2 (37), p. 3-6.

13. Jankauskienè, D., Ališauskienè, R., Navickienė, R., Vaitkevičienė, R. Pacientų dalyvavimo sveikatos apsaugos sistemos procese įvertinimas. Visuomenés sveikata, 2008, T. 3, Nr. 42, p. 1019.

14. Jankauskienė, D. Sveikatos politikos ir valdymo vystymas. Sveikatos politika ir valdymas: mokslo darbai, 2009, p.4-22.

15. Jankauskienè, D. Sveikatos politikos vertybės ir iššūkiai artimiausiame dešimtmetyje. Sveikatos politika ir valdymas: mokslo darbai, 2011, p.7-26.

16. Jankauskienè, D. Sveikatos priežiūros paslaugų kokybès vertinimo pacientų požiūriu palyginimas Lietuvoje ir kai kuriose Europos šalyse. Sveikatos politika ir valdymas: mokslo darbai, 2012, p. 84-101.

17. Janušonis, V. Kokybiška ir tinkama sveikatos priežiūra: pacientų nuomonè ir vertinimas. Tiltai, 2016, Nr.3, p. 49-59.

18. Jung, T. Citizens, Co-producers, Customers, Clients, Captives? A Critical Review of Consumerism and Public Services. Public Management Review, 2010, Vol.12, No.3, p. 39-446.

19. Leonavičius, V. Sociologijos recepcija Lietuvoje: sveikatos sociologijos atvejis. Filosofija. Sociologija, 2003, T.14, Nr.3, p.35-40.

20. Leonavičius, V., Baltrušaitytè, G., Naujokaitè, I. Sociologija ir sveikatos priežiūros paslaugu vartotojas, Kaunas: Vytauto Didžiojo universiteto leidykla, 2007.

21. Lietuvos nacionalinè sveikatos koncepcija. Valstybės žinios, 1991-11-30, Nr. 33-893. 
22. Lietuvos sveikatos programa. Valstybės žinios, 1998-07-17, Nr. 64-1842.

23. Lietuvos TSR Sveikatos apsaugos įstatymas. Vyriausybės žinios, 1971-01-01, Nr. 35-286.

24. LR Alkoholio kontrolès įstatymas. Valstybės žinios, 1995-05-26, Nr. 44-1073.

25. LR Gydytojo medicinos praktikos įstatymas. Valstybès žinios, 1996, Nr. 102-2313.

26. LR Kraujo donorystès įstatymas. Valstybės žinios, 1996-11-29, Nr. 115-2666.

27. LR Pacientų teisių ir žalos sveikatai atlyginimo įstatymas. Valstybės žinios, 1996-10-23, Nr. 1022317.

28. LR Psichikos sveikatos priežiūros įstatymas. Valstybės žinios, 1995-06-28, Nr. 53-1290.

29. LR Maisto įstatymas. Valstybès žinios, 2000-04-19, Nr. 32-893.

30. LR Narkologinès priežiūros įstatymas. Valstybès žinios, 1997-04-09, Nr. 30-711.

31. LR Stomatologinès priežiūros įstatymas. Valstybės žinios, 1996-04-19, Nr. 35-855.

32. LR Sveikatos draudimo įstatymas. Valstybės žinios, 1996-06-12, Nr. 55-1287.

33. LR Sveikatos priežiūros įstaigų ịstatymas. Valstybės žinios, 1996-07-12, Nr. 66-1572

34. LR Sveikatos sistemos įstatymas. Valstybès žinios, 1994-08-17, Nr. 63-1231.

35. LR Tabako kontrolès įstatymas. Valstybès žinios, 1996-02-07, Nr. 11-281.

36. LR Žmonių užkrečiamųjų ligų profilaktikos ir kontrolès įstatymas. Valstybès žinios, 1996-10-30, Nr. 104-2363.

37. LR Visuomenės sveikatos priežiūros ịstatymas. Valstybės žinios, 2002-06-07, Nr. 56-2225.

38. Murauskienè, L. Sveikatos priežiūros valdymas//Pirmasis reformu dešimtmetis: sveikatos priežiūros sektorius socialinių-ekonominių pokyčių kontekste. Černiauskas, G.; Dobravolskas, A.; Murauskienè, L. Vilnius: Sveikatos ekonomikos centras, 2000, p.151-167.

39. Peičius, E., Kučinskaitè, A. Lètinėmis neinfekcinėmis ligomis sergančių pacientų dalyvavimas priimant pirminès sveikatos priežiūros sprendimus: kokybinio tyrimo analizè. Visuomenès sveikata, 2014, Nr. 1, p. 90-97.

40. Petronytė, G., Jasaitytė, R. Nevyriausybinių organizacijų, atstovaujančių pacientų interesus, dalyvavimas valstybès sveikatos politikoje. Sveikatos politika ir valdymas, 2017, T.1, Nr.10, p. $115-131$.

41. Petukienè, E., Tijūnaitienè, R., Raipa, A. Visuomenès dalyvavimas: socialinio kapitalo, demokratijos ir racionalaus pasirinkimo teorijų apžvalga. Viešoji politika ir administravimas, 2007, Nr. 21, p. 87-95.

42. Pūras, D., Šumskienè, E., Veniūtè, M., Šumskas, G., Juodkaitè, D., Murauskienė, L., MataitytėDiržienè, J., Šliužaitė, D. Iššūkiai igyvendinant Lietuvos psichikos sveikatos politika. Mokslo studija. Vilnius: Vilniaus universiteto leidykla, 2013.

43. Sahlsten, M.J, Larsson, I.E, Sjostrom, B., Plos, K.A. An Analysis of the Concept of Patient Participation. Nursing Forum, 2008, Vol. 43, No.1, p. 2-11.

44. Souliotis, K. Patient Participation in Contemporary Health Care: Promoting a Versatile Patient Role. Health Expectations, 2016, Vol.19, No.2, p. 175-178.

45. Souliotis, K., Peppou, L.E., Agapidaki, E., Tzavara, C., Debiais, D., Hasurdjiev, S., Sarkozy, F. Health Democracy in Europe: Cancer Patient Organization Participation in Health Policy. Health Expectations, 2018, Vol.21, No.2, p. 474-484.

46. Tenbensel, T. Public Participation in Health Policy in High Income Countries-Why, Who, What, Which, and Where? Social Science and Medicine, 2010, Vol.71, No.9, p.1537-1540.

47. Thornton, R.D., Nurse, N., Snavely, L., Hackett-Zahler, S., Frank, K., DiTomas R.A. Influences on Patient Satisfaction in Healthcare Centers: A Semi-Quantitative Study over 5 Years. BMC Health Service Research, 2017, Vol. 17, No.361, p.1-9.

48. Thurston, W., MacKean, G., Vollman, A., Casebeer, A., Weber, M., Maloff, B., Bader, J. Public Participation in Regional Health Policy: A Theoretical Framework. Health Policy, 2005, Vol. 73, No. 3, p.237-252.

49. Tijūnaitienè, R., Damkuvienè, M. Visuomenès dalyvavimo koncepcijos: teorinè prieiga. Ekonomika ir vadyba: aktualijos ir perspektyvos, 2010, T.1, Nr. 17, 125-132. 
50. Tritter, J.Q. Revolution or Evolution: The Challenges of Conceptualising Patient and Public Involvement in a Consumerist World. Health Expectations, 2009, No.12, p. 275-87.

51. Vahdat, S., Hamzehgardeshi, L., Hessam, S., Hamzehgardeshi, Z. Patient Involvement in Health Care Decision Making: A Review. Iranian Red Crescent Medical Journal, 2014, Vol.16, No.1, p. $1-7$.

52. Williamson, L. Patient and Citizen Participation in Health: The Need for Improved Ethical Support. American Journal of Bioethics, 2014, Vol.14, No.6, p.4-16.

53. World Health Organisation. Declaration of Ama-Ata. International Conference on Primary Health Care. Alma-Ata, USSR, 1978.

Giedrè Baltrušaitytė

\title{
The Concept of Public Participation in Key Health Policy Documents of the First Decade of Lithuania's Independence (1991 - 2002)
}

\begin{abstract}
The article focuses on the concept of public participation in key national health policy documents that were adopted during the first decade of Lithuania's Independence (1991 - 2004). Seventeen health policy documents are analyzed: National Health Conception (1991), Lithuanian Health Program (1998) and major health system related laws that defined public participation. It is concluded that although the importance of public participation in key health policies has been highlighted, the possibilities for public involvement in health policy or health and healthcare decisionmaking in most of these documents were not clearly defined. Public participation is often seen not as involvement of the public in the processes of shaping or implementing health policies, but as participation of patients in their healthcare through granting them certain rights to make personally significant decisions. The public is also often treated as the object in health or healthcare-related decision-making.
\end{abstract}

Giedre Baltrušaitytè - Vytauto Didžiojo universiteto Socialinių mokslų fakulteto Sociologijos katedros lektorè, socialinių mokslų daktarè.

email: giedre.baltrusaityte@vdu.lt.

Giedre Baltrušaitytè - Doctor of Social Sciences, Assist.Professor at the Department of Sociology, Faculty of Social Sciences, Vytautas Magnus University.

email: giedre.baltrusaityte@ vdu.lt 